\title{
Pengaruh Mediasi Return on Equity dalam Hubungan antara Ukuran Perusahaan dan Penghindaran Pajak
}

\author{
Aprilliani Hutajulu, Francis M. Hutabarat* \\ Universitas Advent Indonesia, Bandung, Indonesia \\ *fmhutabarat@unai.edu
}

\author{
Riwayat Artikel: \\ Tanggal diajukan: \\ 30 Juni 2020 \\ Tanggal diterima: \\ 28 Agustus 2020 \\ Tanggal dipublikasi: \\ 31 Agustus 2020
}

\begin{abstract}
Abstrak
Penelitian ini dilakukan untuk menyelidiki apakah Ukuran Perusahaan dan Return on Equity (ROE) memiliki pengaruh terhadap Tax Avoidance. Penelitian menggunakan data kuantitatif dengan 75 data sampel pada 15 sektor bank yang terdaftar pada BEI berupa laporan keuangan tahun 2014-2018. Sampel penelitian diperoleh dari 15 perusahaan pada industry perbankan yang tercatat dalam BEI yaitu : AGRO, BBCA, BBKP, BBNI, BBRI, BBTN, BBYB, BDMN, BJBR, BJTM, BMRI, BNGA, INPC, MCOR, dan PNBN. Untuk memenuhi hipotesis, diperlukan uji Statistik $F$, Uji $T$ dan analisis regresi. Hasil penelitian menunjukan bahwa Ukuran Perusahaan tidak memiliki pengaruh signifikan terhadap Tax Avoidance (penghindaran pajak) dan ROE berpengaruh signifikan terhadap Tax Avoidance. Dapat disimpulkan bahwa keberadaan ROE sepenuhnya memediasi pengaruh SIZE dan Tax Avoidance.
\end{abstract}

Kata kunci: Tax Avoidance, Ukuran Perusahaan, Return on Equity (ROE).

\section{Pengutipan:}

Hutajulu, A., \& Hutabarat, F. M. (2020). Pengaruh Mediasi Return on Equity Dalam Hubungan Antara Ukuran Perusahaan dan Penghindaran Pajak. Jurnal Ilmiah Akuntansi dan Humanika, 10 (2), 204-2013

Keywords: Tax Avoidance, Size, Return on Equity (ROE)

\section{Abstract}

This study was conducted to investigate whether Company Size and Return on Equity (ROE) have an influence on Tax Avoidance. The study uses quantitative data with 75 sample data in 15 banking sectors listed on the IDX in the financial statements from 2014-2018. Research samples were obtained from 15 companies in the banking industry listed on the IDX, namely: AGRO, BBCA, BBKP, BBNI, BBRI, BBTN, BBYB, BDMN, BJBR, BJTM, BMRI, BNGA, INPC, MCOR, and PNBN. To fulfill the hypothesis, statistical $F$ test, $T$ test and regression analysis are needed. The results showed that company size had no significant effect on tax avoidance and ROE had a significant effect on tax avoidance. It can be concluded that the existence of ROE fully mediates the influence of SIZE and Tax Avoidance.

\section{Pendahuluan}

Pertumbuhan industri dindonesia terutama pada perbankan terlihat cukup signifikan. Hal ini terlihat dari banyaknya industry bank yang berdiri di Indonesia. Pada sector perbankan perannya sangat penting untuk menggerakan perekonomian pada Indonesia dilihat dari kesehatan bank juga stabilitasnya. Perusahaan perbankan yang memiliki kesehatan yang baik dan dapat mengelola beban pajaknya dapat membantu perekonomian di Indonesia agar dapat maju. Wajib pajak yang ada di Indonesia dikelompokan menjadi 2, yaitu WP orang pribadi dan WP badan. Bagi WP merupakan pemberian dalam meningkatkan pembangunan nasional. Perusahaan mengusahakan pengurangan pembayaran pajak lebih rendah dengan begitu income atau laba bersih perusahaan tidak berkurang. 
Pembayaran pajak di Indonesia memiliki lingkungan khusus bagi perusahaan dan terkadang kurang ditanggapi dengan baik. Hal itu menyebabkan pemerintah Indonesia melakukan reformasi perpajakan pada tahun 2008 sehingga dikeluarkanlah revisi UndangUndang Nomor 36 Tahun 2008. Hasil yang didapat dalam perbaikan yaitu pemberian insentif bagi PPh badan berupa pengurangan tarif pajaknya. Adanya tarif efektif pajak akan memberi dampak yang efisien pada beban pajak perusahaan sehingga diperoleh laba bersih yang maksimal dan memberikan pertumbuhan pada ekuitas perusahaan. Tax avoidance adalah suatu usaha dalam menghindari pajak tetapi diperbolehkan atau bersifat resmi. (Dewi \& Jati, 2014) menyebutkan Tax avoidance yang dilakukan tidaklah berlawanan pada perundangundangan pajak karena perilaku pada tax avoidance memanfaatkan peluang penerimaan negara pada sector pajak dari peraturan tersebut. Penghindaran pajak dilakukan pada beberapa perusahaan berdasarkan keputusan yang diambil oleh para pemimpin yang bersangkutan. Menurut penelitian (Hashemi Rodhian Hanum \& Zulaikha, 2013) Jumlah laba yang dihasilkan membuat pajak mendapatkan perhatian yang lebih karena saling berhubungan. Dengan melihat tarif efektif pada sebuah perusahaan dapat mengukur seberapa baik pengelolaan pajak dalam perusahaan tersebut.

Ukuran perusahaan adalah alat yang berguna dalam mengukur kecil atau besarnya asset (kekayaan) yang akan di miliki oleh perusahaan. Ukuran perusahaan adalah pengukuran untuk menyatakan apakah perusahaan tersebut mempunyai kegiatan operasional yang terorganisir sehingga dapat diatur oleh manajemen laba (Kusumawardhani, 2012). Menurut penelitian (Kurniasih \& Ratna Sari, 2013) Semakin besar ukuran perusahaan membuat pemerintah memiliki perhatian lebih pada perusahaan tersebut untuk melihat adanya tindakan kepatuhan atau perilaku penghindaran pajak. Kemampuan dalam pemenuhan kewajiban pajak dapat dipengaruhi oleh ukuran perusahaan dan dapat menjadi faktor penyebab adanya tax avoidance. Ada beberapa faktor yang menyebabkan manajemen melakukan tindakan tax avoidance yaitu profitabilitas, tata Kelola perusahaan, dan karakteristik manajemen (Maharani \& Suardana, 2014).

Rasio ROE atau return on equity dapat dikatakan laba atas ekuitas. Dalam perusahaan pengukuran income (penghasilan) yang diperoleh perusahaan dari modal yang dinvestasikan dapat dilihat dari Return on equity (ROE) atau profitabilitasnya. Pada perusahaan besar mereka sanggup untuk membayar kewajiban dan mendapatkan laba. Dalam penelitian ini untuk memperkirakan besarnya profitabilitas digunakanlah perhitungan ROE (Return On Equity) untuk melihat kompetensi penghasilan laba dari keseluruhan modal yang dimiliki perusahaan. Semakin baik nilai dari ROE pada perusahaan, maka hasil kinerjanya juga semakin baik dalam meperoleh laba bersih setelah pajak.

Menurut berita yang termuat pada situs kontan yang diberitakan oleh (Sitanggang, 2019) Kemampuan bank besar mencetak laba semakin kuat. Pada PT Bank Central Asia Tbk ROA tertinggi yang didapat yaitu $4 \%$ secara tahunan disebabkan tingginya laba sebelum pajak sebesar $12,2 \%$ di tahun 2018. Selain BCA, ROA Bank Mandiri juga meningkat sebesar $3,17 \%$. ROA Bank Mandiri diangkat dari laba sebelum pajak yang meningkat menjadi $25 \%$. Rasio akan diusahakan stabil dengan adanya kredit di sekitar $10 \%$ sampai $12 \%$.Dalam kasus lain, menurut (Walfajri, 2018) Unit Usaha Syariah bank CIMB Niaga Syariah menaikkan kinerja laba dengan baik. CIMB NIAGA mengalami peningkatan laba sebelum pajak sebesar $47,9 \%$ memberikan andil bagi induk usaha. Hal ini menerangkan Return On Equity (ROE) di tahun 2018 sebesar 2,9\% .

Pada kasus lain, menurut (Jatmiko, 2020) PT Bank Permata Tbk pada kuartal I tahun 2020 mengalami laba bersih yang turun menjadi 99,53\% disebabkan adanya penambahan beban operasional, dan beban pajaknya . Dengan demikian dari kasus diatas dapat dilihat bahwa kondisi perubahan profitabilitas (ROE) dan ukuran perusahaan dari tahun ke tahun mengalami perubahan dalam laba bank yang berpengaruh pada pajak. Penelitian terdahulu menunjukan bagaimana ukuran perusahaan, profitabilitas dan variable lain dapat mempengaruhi penghindaran pajak atau faktor apa yang dapat menjadi faktor peghindaran pajak perusahaan. Pada penelitian ini peneliti merasa perlu mengadakan penelitian mengenai Ukuran Perusahaan terhadap Tax Avoidance (penghindaran pajak) dengan 
menggunakan Return On Equty sebagai variable mediasi dengan metode mediasi yang belum digunakan pada penelitian sebelumnya.

\section{Ukuran Perusahaan}

Ukuran perusahaan atau Size adalah penilaian perusahaan berdasarkan besaran nilai ekuitas, aset atau penjualannya (Riyanto, 2008, p. 313). Ukuran perusahaan dilihat dari total asset, karena size ini memiliki stabilitas lebih dan berkelanjutan setiap periode (Yogiyanto, 2007, p. 282). Ukuran perusahaan atau size adalah perbandingan yang dapat mengelompokkan perusahaan dari yang besar hingga kecil dengan beberapa cara yaitu total asset, nilai pasar saham, dan tingkat penjualan (Machfoedz (1994), pada (Suwito \& Herawaty, 2005). Ukuran perusahaan atau size menjadi gambaran total asset milik perusahaan tersebut. Dengan ukuran suatu perusahaan yang besar, maka asset yang dimiliki perusahaan pun bertambah besar dan pengeluaran yang dikeluarkan dalam kegiatan operasional menjadi bertambah. Keputusan yang dilakukan manajemen dalam pendanaan untuk mendapatkan nilai perusahaan yang ideal dilihat dari seberapa besar perusahaan tersebut. Untuk menilai ukuran perusahaan dirumuskan seperti berikut:

$$
\text { SIZE }=\text { Ln (Total Asset }) \times 100 \%
$$

\section{Return on Equity}

Rasio Return on Equity atau ROE dapat disebut laba atas ekuitas. Rasio ini meninjau kemampuan perusahaan untuk menghasilkan laba atas ekuitas dari sumber daya yang ada. Return on Equity atau ROE bertujuan menilai berapa besar keuntungan yang dimiliki oleh pemilik dari modal (Harjito \& Martono, 2012). Hasil dari ROE ( Return on Equity) adalah rasio yang mengindikasikan peran modal dalam menghasilkan laba bersih (Hery, 2015, p. 230). Dalam perhitungan ROE, perusahaan menggunakan laba bersih dan ekuitas. Rasio ini termasuk profitabilitas dilihat dari pandangan shareholders, jika ROE tinggi menandakan perusahaan mempunyai peluang untuk memberikan keuntungan untuk shareholders. Semakin tinggi profitabilitas di perusahaan, membuat investor terdorong untuk mengambil atau mencari saham yang ada. Dan diharapkan suatu saat akan menghasilkan pengembalian yang tinggi dari pelibatan yang besar (Ikhwal, 2016). Dalam pengukuran kinerja suatu perusahaan, salah satu indikatornya adalah Laba bersih perusahaan. Rumus menghitung ROE adalah :

$$
\mathrm{ROE}=\frac{\text { Net } \text { Profit After } \text { Tax }}{\text { Stockholders Equity }}
$$

\section{Tax Avoidance}

Berdasarkan (Xynas, 2011) Tax Avoidance adalah upaya yang dianggap resmi dalam pengurangan utang pajak. Dalam kinerja operasional perusahaan, Tax Avoidance merupakan usaha untuk meminimalkan pembayaran pajak berdasarkan ketentuan penetapan peraturan perpajakan tetapi ada pengistimewaan dan potongan yang dibuat berdasarkan kebijakan pemimpin perusahaan. Zain (2010) mengatakan penghindaran pajak merupakan cara untuk mengurangi atau menghapuskan tax expense (Selviani et al., 2018) dengan pertimbangan resiko pajak yang ditimbulkan. Tax Avoidance bukanlah penyalahgunaan UU perpajakan karena tindakan WP dalam pengurangan, penghindaran, meminimalisir tax expense dilakukan cara yang ditetapkan UU perpajakan. Untuk menghitung Tax Avoidance digunakan rumus CETR, rasio ini dicari dengan perbandingan antara pemenuhan pajak dengan laba sebelum pajak, dan dirumuskan seperti berikut:

$$
\text { CETR }=\frac{\text { Pembayaran pajak }}{\text { Laba sebelum pajak }}
$$




\section{Pembahasan Hipotesis}

\section{Ukuran Perusahaan dan Tax Aoidance}

Ukuran perusahaan digolongkan menjadi beberapa jenis yaitu perusahaan kecil, perusahaan sedang hingga perusahaan besar. Perusahaan yang besar dalam mengatur beban pajaknya akan lebih memiliki pertimbangan resiko (Rinaldi \& Cheisviyanny, 2015). Besarnya ukuran perusahaan membuat nilai CETR yang dimiliki rendah, disebabkan karena perusahaan besar memadai dalam mengelola sumber daya yang ada sehingga produktif dalam merencanakan pajaknya. Menurut (Selviani et al., 2018) ; (Viola Syukrina E Janrosl, 2018); (Putri \& Putra, 2017) mengatakan adanya pengaruh yang signifikan positif antara Ukuran Perusahaan dan Tax Avoidance.

\section{$\mathrm{H}_{1}$ : Ada pengaruh yang signifikan antara SIZE dan Tax Avoidance}

\section{ROE dan Tax Avoidance}

Suatu tolak ukur dari income yang dimiliki pemilik perusahaan dari modal yang diinvestasikan disebut profitabilitas atau ROE. Perusahaan dengan tingkat profitabilitas tinggi membuat pembayaran pajaknya juga akan tinggi. (Derashid \& Zhang, 2003). Semakin baik perusahaan, maka tarif pajak efektifnya menjadi kecil karena pembayaran pajaknya lebih rendah. Penelitian yang dilakukan oleh (Mahdiana \& Amin, 2020); (Pitaloka \& Aryani Merkusiawati, 2019); (Sanny \& Warastuti, 2020) yang mengatakan adanya pengaruh signifikan Positif antara ROE dan Tax Avoidance

\section{$\mathrm{H}_{2}$ : Adanya pengaruh yang signifikan antara ROE dan Tax Avoidance}

\section{Metode}

Penelitian dilakukan menggunakan populasi yang menjadi total dari seluruh objek dalam penelitian, sementara sampel merupakan komponen dari populasi yang dijadikan objek penelitian. Populasi pada penelitian yaitu perusahaan perbankan yang telah tercatat dan telah memuat laporan keuangan perusahaan dalam BEI atau Bursa Efek Indonesia mulai tahun 2014-2018. Untuk mendapatkan sampel dilakukanlah teknik Purposive Sampling dalam sector keuangan ini didapatlah 15 sampel perusahaan dengan yang digunakan dengan kriteria sebagai berikut:

1. Penelitian dilakukan pada perusaahaan perbankan yang tercatat pada BEI atau Bursa Efek Indonesia dengan laporan tahunan lengkap dari tahun 2014-2018.

2. Pada perusahaan ini digunakan sejumlah 75 sampel data.

3. Perusahaan dalam periode penelitian tidak mengalami kerugian

4. Penelitian dalam penyajian laporan keuangan tahunannya disatukan dengan mata uang rupiah.

Teknik untuk mengumpulkan data yang digunakan pada penelitian yaitu documenter dengan memilih pengambilan data keuangan dari annual report pada perusahaan perbankan yang telah melewati rangkaian proses yang tervalidasi dalam website. Pengambilan data juga berasal dari beberapa referensi dari penelitian terdahulu, artikel yang berhubungan dengan penelitian, dan juga terdapat pada buku yang ditulis oleh penulis yang edukatif. Pada penelitian ini Ukuran perusahaan dan Return on Equity digunakan menjadi Variabel X ( Independen ) \& Tax Avoidance digunakan Variabel Y (Dependen ). Teknik menganalisis data yaitu metode asumsi klasik seperti descriptive statistics, significant test dan juga regresi. Untuk memperoleh hipotesis berupa uji $\mathrm{F} \&$ uji $T$, perlu melakukan analisa regresi linear berganda. Pengolahan data pada penelitian dibantu oleh program SPSS. 


\section{Hasil dan Pembahasan \\ Descriptive Statistic}

Tabel 1. Desc. Stat

\begin{tabular}{lrrrrr}
\hline & N & \multicolumn{1}{c}{ Min } & \multicolumn{1}{c}{ Max } & \multicolumn{1}{c}{ Mean } & \multicolumn{1}{c}{ Std. Dev } \\
\hline ETR & 75 & .00 & .72 & .2399 & .11454 \\
ROE & 75 & -22.73 & 31.19 & 12.6213 & 8.49758 \\
SIZE & 75 & 6.03 & 20.91 & 14.8440 & 4.28856 \\
Valid N & 75 & & & & \\
(listwise) & & & & & \\
\hline
\end{tabular}

Data diolah (2020)

Hasil pada table descriptive statistic ini terkait pada variable Tax Avoidance yaitu nilai ETR yaitu $23.99 \%<25 \%$ menyatakan nilai dibawah standar pembayaran pajak yang ada di Indonesia. Sedangkan variable lain menunjukkan profitabilitas yang mengacu pada ROE memiliki nilai melebihi standar yang ditetapkan Bank Indonesia yaitu $12.62 \%>12 \%$. Rata-rata ukuran perusahaan sebesar $14.84 \%$. Dari hasil descriptive statistic ini pembayaran pajak pada bank yang diteliti memiliki rasio dibawah standar, sedangkan kondisi keuangan pada perusahan perbankan ini masih aman dan berada pada standar kesehatan bank yang ditetapkan.

Koefisien Determinasi

Tabel 2. Determination

\begin{tabular}{|c|c|c|c|c|c|c|c|c|c|}
\hline \multirow[b]{2}{*}{ Model } & \multirow[b]{2}{*}{$\mathrm{R}$} & \multirow[b]{2}{*}{$\mathrm{R}^{2}$} & \multirow[b]{2}{*}{ Adj $R^{2}$} & \multirow{2}{*}{$\begin{array}{l}\text { Std. Err of } \\
\text { the } \\
\text { Estimate }\end{array}$} & \multicolumn{5}{|c|}{ Chg Stat } \\
\hline & & & & & $\begin{array}{c}\mathrm{R}^{2} \\
\text { Chg }\end{array}$ & $\begin{array}{c}\mathrm{F} \\
\text { Chg }\end{array}$ & df1 & df2 & Sig. F Chg \\
\hline 1 & $.089^{a}$ & .008 & -.006 & .11486 & .008 & .582 & 1 & 73 & .448 \\
\hline 2 & $.219^{b}$ & .048 & .021 & .11331 & .040 & 3.013 & 1 & 72 & .087 \\
\hline
\end{tabular}

a. Pred: (Constant), SIZE

b. Pred: (Constant), SIZE, ROE

Tabel 2 menunjukkan bahwa pada model 1 nilai R-Square adalah sebesar .008 yang berarti kontribusi SIZE terhadap perubahan pada Tax Avoidance adalah sebesar $0.8 \%$. Terkait model 2, didapati bahwa dengan mediasi ROE maka didapati kontribusi SIZE dan ROE terhadap perubahan pada Tax Avoidance menjadi sebesar $4.8 \%$ dan didapati perubahan dalam nilai R-Square change sebesar 0.04 atau $4 \%$.

Significant Test

Tabel 3. ANOVA

\begin{tabular}{llrrrrr}
\hline Mdl & & $\begin{array}{c}\text { Sum of } \\
\text { Squares }\end{array}$ & Df & Mn Square & \multicolumn{1}{c}{ F } & Sig. \\
\hline 1 & Regression & .008 & 1 & .008 & .582 & $.448^{\mathrm{a}}$ \\
& Residual & .963 & 73 & .013 & & \\
& Total & .971 & 74 & & & \\
\hline 2 & Regression & .046 & 2 & .023 & 1.805 & $.172^{\mathrm{b}}$ \\
& Residual & .924 & 72 & .013 & & \\
& Total & .971 & 74 & & & \\
\hline
\end{tabular}

a. Pred: (Constant), SIZE

b. Pred: (Constant), SIZE, ROE 
Tabel 3. ANOVAc

\begin{tabular}{llrrrrr}
\hline Mdl & & $\begin{array}{c}\text { Sum of } \\
\text { Squares }\end{array}$ & Df & Mn Square & \multicolumn{1}{c}{ F } & \multicolumn{1}{c}{ Sig. } \\
\hline 1 & Regression & .008 & 1 & .008 & .582 & $.448^{\mathrm{a}}$ \\
& Residual & .963 & 73 & .013 & & \\
& Total & .971 & 74 & & & \\
\hline 2 & Regression & .046 & 2 & .023 & 1.805 & $.172^{\mathrm{b}}$ \\
& Residual & .924 & 72 & .013 & & \\
& Total & .971 & 74 & & & \\
\hline
\end{tabular}

a. Pred: (Constant), SIZE

c. Dep Var: ETR

Hasil dari uji signifikan menunjukkan bahwa pada model 1 tidak ada pengaruh signifikan antara SIZE terhadap Tax Avoidance. Hasil menyatakan nilai F-test .582 dan nilai significant 0.448 pada $\alpha=0.05$ atau $5 \%$. Sedangkan pada model 2, didapati bahwa dengan adanya mediasi ROE maka didapati pengaruh SIZE, ROE terhadap Tax Avoidance adalah significant dengan tingkat signifikan 0.172 pada $\alpha=0.05$ atau $5 \%$ dengan $F$-test 1.805 .

Regression

Tabel 4. Koefisien ${ }^{a}$

\begin{tabular}{|c|c|c|c|c|c|c|}
\hline \multirow[b]{2}{*}{ Mdl } & & \multicolumn{2}{|c|}{$\begin{array}{l}\text { Unstd } \\
\text { Coeff }\end{array}$} & \multirow{2}{*}{$\begin{array}{l}\text { Std } \\
\text { Coeff } \\
\text { Beta } \\
\end{array}$} & \multirow[b]{2}{*}{$t$} & \multirow[b]{2}{*}{ Sig. } \\
\hline & & $B$ & Std. Error & & & \\
\hline \multirow[t]{2}{*}{1} & (Constant) & .275 & .048 & & 5.745 & .000 \\
\hline & SIZE & -.002 & .003 & -.089 & -.763 & .448 \\
\hline \multirow[t]{3}{*}{2} & (Constant) & .314 & .052 & & 6.004 & .000 \\
\hline & SIZE & -.003 & .003 & -.102 & -.882 & .381 \\
\hline & ROE & -.003 & .002 & -.200 & -1.736 & .087 \\
\hline
\end{tabular}

\section{a. Dependent Variable: ETR}

Hasil uji signifikan menunjukkan bahwa diantara variable independent maka terlihat bahwa pada model 1 tidak ada pengaruh signifikan pada variable SIZE terhadap Tax Avoidance dengan nilai signifikan 0.448 pada level signifikan $10 \%$. Sedangkan pada model 2, didapati dengan adanya mediasi ROE, didapati bahwa SIZE dan Tax Avoidance tetap memiliki pengaruh yang tidak signifikan yaitu 0.381 pada level signifikan $10 \%$. Dan terkait ROE dan Tax Avoidance didapati adanya pengaruh yang signifikan dengan level signifikan 0.087 pada level signifikan 10\%. Dengan demikian keberadaan ROE sepenuhnya memediasi pengaruh SIZE dan Tax Avoidance.

\section{Diskusi}

Hasil Penelitian berdasarkan pada hipotesa yang dibuat dalam studi ini. Pada penelitian ini didapati bahwa hipotesa pertama memiliki pernyataan ada pengaruh yang signifikan antara SIZE dan Tax Avoidance. SIZE merupakan ukuran perusahaan dengan proxy total asset. Hasil penelitian mengatakan tidak adanya pengaruh yang signifikan antara SIZE dan Tax Avoidance. Hasil ini didukung penelitian terdahulu dari (Mahdiana \& Amin, 2020) ; (Prihananto, 2018) ; (Barli, 2018) yang mengatakan tidak ada pengaruh signifikan antara size dan Tax Avoidance. Sedangkan menurut (Selviani et al., 2018) ; (Janrosl \& Efriyenti, 2018) ; (Putri \& Putra, 2017) mengatakan adanya pengaruh yang signifikan positif antara SIZE dan Tax Avoidance. 
Pada penelitian dalam hipotesa kedua memiliki pernyataan adanya pengaruh yang signifikan antara ROE dan Tax Avoidance. ROE merupakan rasio yang mengukur tingkat keuntungan perusahaan dan banyak digunakan oleh para investor. Hasil penelitian menjelaskan ada pengaruh signifikan antara ROE dan Tax Avoidance pada model 2 . Hasil ini didukung penelitan terdahulu dari (Mahdiana \& Amin, 2020); (Pitaloka \& Aryani Merkusiawati, 2019); (Dewi Putriningsih et al., 2019) yang mengatakan adanya pengaruh signifikan Positif antara ROE dan Tax Avoidance. Sedangkan menurut ; (Arianandini \& Ramantha, 2018a) ; (Hidayat, 2018b) mengatakan tidak adanya pengaruh yang signifikan antara ROE dan Tax Avoidance.

\section{Size dan Tax Avoidance}

Dari hasil analisis regresi penelitian memperlihatkan koefisien pada variable ukuran perusahaan pada model 1 adalah -.002 dengan nilai signifikan .448 dan pada model 2 sebesar -.003 pada nilai signifikan .381. Maka hasil yang diketahui SIZE tidak ada pengaruh signifikan terhadap Tax Avoidance diketahui $\mathrm{H} 1$ ditolak. Hasil telah didukung penelitian terdahulu dari Mahdiana dan Amin (2020) ; Prihananto, Nuraina dan Sulistyowati (2018) ; Barli (2018) yang mengatakan tidak ada pengaruh signifikan antara size dan tax avoidance. Sedangkan menurut Selviani, Supriyanto dan Fadillah (2018) ; Janrosl dan Efriyenti (2018) ; Putri dan Putra (2017) mengatakan adanya pengaruh yang signifikan positif antara SIZE dan Tax Avoidance

Berdasarkan pada data diatas disebutkan bahwa ukuran perusahaan pada perusahaan perbankan pada tahun 2015-2018 menunjukkan SIZE tidak memiliki pengaruh terhadap tax avoidance dimana ukuran perusahaan besar akan memiliki nilai CETR yang rendah karena memiliki kemampuan lebih dalam penggunaan sumber daya yang ada dalam perencanaan pajaknya. Hal tersebut sejalan dengan penelitian (Astuti \& Aryani, 2016) dan (Dharma dan Ardiana, 2016). Ukuran perusahaan yang besar pada perusahaan perbankan ini menunjukan laba bersih yang didapat dari sumber daya perusahaan tidak terlalu mempengaruhi tax expense sehingga perusahaan kurang melakukan penerapan tax avoidance.

\section{Return on Equity dan Tax Avoidance}

Dari hasil analisis regresi penelitian ini memperlihatkan koefisien pada variable Return on Equity didapati adanya pengaruh yang signifikan terhadap Tax Avoidance dengan level signifikan 0.087 pada level signifikan 10\%, dengan itu $\mathrm{H} 2$ diterima. Hasil ini didukung penelitan terdahulu dari Mahdiana, dan Amin (2020) ; Pitaloka \& Aryani (2019) ; Putriningsih, Suyono \& Herwiyanti (2019) yang mengatakan adanya pengaruh signifikan antara ROE dan Tax Avoidance. Sedangkan menurut Rozak, Hardiyanto dan Fadillah (2019) ; Arianandini dan Ramantha (2018); Hidayat (2018) mengatakan tidak adanya pengaruh signifikan antara ROE dan Tax Avoidance.

Berdasarkan pada data profitabilitas perusahaan yaitu ROE pada perusahaan perbankan yang diteliti pada tahun 2015-2018. Perusahaan memiliki tingkat profitabilitas 12.6 pada $\mathrm{ROE}$, berada diatas standar rata-rata pada table. Penting bagi perusahaan dalam memperhatikan tingkat profitabilitasnya dengan meningkatkan ROE. Hal tersebut sejalan dengan penelitian (Sanjaya dan Rizky, 2018) dan Lubis, Sinaga dan Sasongko (2017) yang mengatakan pentingnya profitabilitas dengan ROE. Perusahaan yang mengelola modal yang diinvestasikan dengan baik untuk meningkatkan laba perusahaan akan memperhatikan pengelolaan pajaknya sehingga diperoleh keuntungan berupa dispensasi pajak sehingga perusahaan cendrung terlihat melakukan penghindaran pajak.

\section{Simpulan dan Saran}

Menurut dari hasil penelitian yang diperoleh tentang pengaruh variable Size pada Perusahaan dan ROE terhadap Tax Avoidance di 15 bank terkemuka di Indonesia dengan 75 sampel data pada periode 2014-2018. Dapat disimpulkan pada Size atau Ukuran Perusahaan tidak memiliki pengaruh signifikan pada Tax Avoidance. Sedangkan hal lain yaitu ROE memiliki pengaruh signifikan pada Tax Avoidance. Dapat disimpulkan 
keberadaan ROE sepenuhnya memediasi pengaruh SIZE dan Tax Avoidance.

Peneliti melihat bahwa adanya hubungan antara Ukuran perusahaan, dengan mediasi ROE akan mempengaruhi Tax Avoidance. Sehingga peneliti merekomedasikan beberapa hal seperti berikut. Pertama, perusahaan lebih memperhatikan laporan pada keuangan untuk menjadi penilaian bagi calon investor. Kedua, untuk menghindari kebangkrutan perusahaan diharuskan waspada dalam memberi keputusan untuk menambah modal atau hutang karena resiko dari hutang yang tinggi berdampak buruk dalam perusahaan. Ketiga, setiap manajemen perusahaan perlu mencermati dan mengawasi perusahaan dalam kegiatan meminimalisir penghindaran pajak. Dan terakhir, para peneliti selanjutnya diharapkan dapat melaksanakan penelitian dengan sampel yang berbeda serta ruang lingkup lebih besar dalam Bursa Efek Indonesia.

\section{Daftar Rujuka}

Arianandini, P. W., \& Ramantha, I. W. (2018). Pengaruh Profitabilitas, Leverage, dan Kepemilikan Institusional Pada Tax Avoidance. E-Jurnal Akuntansi, 22(3), 2088-2116. https://doi.org/10.24843/eja.2018.v22.i03.p17

Astuti, T. P., \& Aryani, Y. A. (2016). Tren Pengindaran Pajak Perusahaan Manufaktur di Indonesia. Jurnal Akuntansi, 20(3), 375-388.

Barli, H. (2018). Pengaruh Leverage dan Firm Size Terhadap Penghindaran Pajak (Studi Empiris pada Perusahaan sektor Property, Real Estate dan Building Construction yang Terdaftar di Bursa Efek Indonesia Periode Tahun 2013-2017). Jurnal IImiah Akuntansi Universitas Pamulang, 6(2), 223-238.

Derashid, C., \& Zhang, H. (2003). Effective tax rates and the "industrial policy" hypothesis: Evidence from Malaysia. Journal of International Accounting, Auditing and Taxation, 4562. https://doi.org/10.1016/S1061-9518(03)00003-X

Dewi, N. N. K., \& Jati, I. K. (2014). Karakteristik Eksekutif, Karakteristik Perusahaan, dan Dimensi Tata Kelola Perusahaan yang Baik Pada Tax Avoidance. E-Jurnal Akuntansi Udayana, 6(2), 249-260.

Dewi Putriningsih, Eko Suyono, \& Eliada Herwiyanti. (2019). Profitabilitas, Leverage, Komposisi Dewan Komisaris, Komite, dan Kompensasi Rugi Fiskal Terhadap Penghindaran Pajak Pada Perusahaan Perbankan. Jurnal Bisnis dan Akuntansi, 20(2), 77-92. https://doi.org/10.34208/jba.v20i2.412

Dharma, I., \& Ardiana, P. (2016). Pengaruh Leverage, Intensitas Aset Tetap, Ukuran Perusahaan, Dan Koneksi Politik Terhadap Tax Avoidance. E-Jurnal Akuntansi, 15(1), 584-613.

Harjito, D. ., \& Martono. (2012). Manajemen Keuangan (Edisi Kedu). Yogyakarta: Ekonisia.

Hashemi Rodhian Hanum, \& Zulaikha. (2013). Pengaruh Karakteristik Perusahaan Corporate Governance Terhadap Effective Tax Rate(Studi Empiris pada BUMN yang Terdaftar di BEI (2009-2011). Diponegoro Journal of Accounting, 2(2).

Hery. (2015). Analisis Laporan Keuangan. Yogyakarta: CAPS.

Hidayat, W. W. (2018). Pengaruh Profitabilitas, Leverage dan Pertumbuhan Penjualan Terhadap Penghindaran Pajak. Jurnal Riset Manajemen dan Bisnis (JRMB) Fakultas Ekonomi UNIAT, 3(1), 19-26. https://doi.org/10.36226/jrmb.v3i1.82 
Ikhwal, N. (2016). Analisis ROA dan ROE Terhadap Profitabilitas Bank di Bursa Efek Indonesia. Al-Masraf: Jurnal Lembaga Keuangan dan Perbankan, 1(2), 211-227.

Janrosl, V. S. E., \& Efriyenti, D. (2018). Analisis Pengaruh Ukuran Perusahaan, Leverage Dan Profitabilitas Terhadap Tax Evoidance Pada Bank Riau Kepri Tbk. Seminar Nasional IImu Sosial dan Teknologi 1 (SNISTEK 1), (1), 169-174.

Jatmiko, A. (2020). Beban Melonjak, Laba Bersih Bank Permata Anjlok 99,53\%. Diambil dari https://katadata.co.id/agungjatmiko/finansial/5eb8b2aa74f5b/beban-melonjak-lababersih-bank-permata-anjlok-9953

Kurniasih, T., \& Ratna Sari, M. (2013). Pengaruh Return On Assets, Leverage, Corporate Governance, Ukuran Perusahaan dan Kompensasi Rugi Fiskal Pada Tax Avoidance. Buletin Studi Ekonomi, 18(1), 58-66.

Kusumawardhani, I. (2012). Pengaruh Corporate Governance, Struktur Kepemilikan, dan Ukuran Perusahaan Terhadap Manajemen Laba. Jurnal Akuntansi dan Sistem Teknologi Informasi, 9(1), 41-54.

Lubis, I. L., Sinaga, B. M., \& Sasongko, H. (2017). Pengaruh Profitabilitas, Sruktur Modal, Dan Likuiditas Terhadap Nilai Perusahaan. Jurnal Aplikasi Bisnis dan Manajemen, 3(3), 458-465. https://doi.org/10.17358/jabm.3.3.458

Maharani, I., \& Suardana, K. (2014). Pengaruh Corporate Governance, Profitabilitas, Dan Karakteristik Eksekutif Pada Tax Avoidance Perusahaan Manufaktur. E-Jurnal Akuntansi Universitas Udayana, 9(2), 525-539.

Mahdiana, M. Q., \& Amin, M. N. (2020). Pengaruh Profitabilitas, Leverage, Ukuran Perusahaan, Dan Sales Growth Terhadap Tax Avoidance. Jurnal Akuntansi Trisakti, 7(1), 127-138. https://doi.org/10.25105/jat.v7i1.6289

Mas'ud Macfoedz. (1994). Financial Ratio Analysis and The Prediction of Earnings Changes in Indonesia. Kelola: Gajah Mada University Business Review, III(7), 114-137.

Pitaloka, S., \& Aryani Merkusiawati, N. K. L. (2019). Pengaruh Profitabilitas, Leverage, Komite Audit, dan Karakter Eksekutif Terhadap Tax Avoidance. E-Jurnal Akuntansi, 27(2), 1202-1230. https://doi.org/10.24843/eja.2019.v27.i02.p14

Prihananto. (2018). Pengaruh Ukuran Perusahaan, Profitabilitas, Dan Risiko Perusahaan Terhadap Tax Avoidance (Studi Kasus Pada Perusahaan Jasa Di BEI. In FIPA: Forum Ilmiah Pendidikan Akuntansi, 6(2).

Putri, V. R., \& Putra, B. I. (2017). Pengaruh Leverage, Profitability, Ukuran Perusahaan dan Proporsi Kepemilikan Institusional Terhadap Tax Avoidance. Jurnal Manajemen Dayasaing, 19(1), 1-11. https://doi.org/10.23917/dayasaing.v19i1.5100

Rinaldi, \& Cheisviyanny, C. (2015). Pengaruh Profitabilitas, Ukuran Perusahaan dan Kompensasi Rugi Fiskal Terhadap Tax Avoidance ( Studi Empiris Pada Perusahaan Manufaktur Yang Terdaftar Di BEI Tahun 2010-2013 ). Seminar Nasional Ekonomi Manajemen Dan Akuntansi (Snema) Fakultas Ekonomi Universitas Negeri Padang, 472-483.

Riyanto, B. (2008). Dasar-Dasar Pembelanjaan Perusahaan. Yogyakarta: BPFE. 
Rozak, T. S., Hardiyanto, A. T., \& Fadilah, H. (2019). Pengaruh Profitabilitas, Likuiditas, dan Leverage Terhadap Tax Avoidance (Studi Empiris pada Perusahan Manufaktur Sektor Aneka Industri yang terdaftar di Bursa Efek Indonesia periode 2013-2017). Jurnal Online Mahasiswa (JOM) Bidang Akuntansi, 5(5).

Sanjaya, S., \& Rizky, M. (2018). Analisis Profitabilitas dalam menilai kinerja keuangan pada PT Taspen (Persero) Medan. JUrnal KITABAH, 2(2), 277-293. https://doi.org/10.5151/cidi2017-060

Selviani, R., Supriyanto, J., \& Fadillah, H. (2018). Pengaruh Ukuran Perusahaan dan Leverage terhadap Penghindaran Pajak Studi Kasus Empiris Pada Perusahaan Sub Sektor Kimia di Bursa Efek Indonesia Periode 2013 - 2017. Jurnal Online Mahasiswa Bidang Akuntansi, 5(5).

Sitanggang, L. M. S. (2019). Profitabilitas Bank Besar Kian Perkasa. Diambil dari https://insight.kontan.co.id/news/profitabilitas-bank-besar-kian-

perkasa\#: :text=KONTAN.CO.ID - JAKARTA, di posisi 3\%2C15\%25.

Suwito, E., \& Herawaty, A. (2005). Analisis Pengaruh Karakteristik Perusahaan Terhadap Tindakan Laba Yang Dilakukan Oleh Perusahaan Yang Terdaftar Di Bursa Efek Jakarta. Simposium Nasional Akuntansi VIII. Solo.

Walfajri, M. (2018). Bersinergi dengan induk, UUS CIMB Niaga cetak pertumbuhan laba yang tinggi. Diambil dari https://keuangan.kontan.co.id/news/bersinergi-dengan-indukuus-cimb-niaga-cetak-pertumbuhan-laba-yang-tinggi

Xynas, L. (2011). Tax Planning, Avoidance and Evasion in Australia 1970-2010: The Regulatory Responses and Taxpayer Compliance. Revenue Law Journal, 20(1), 1-37. https://doi.org/http://dx.doi.org/10.1057/jird.2012.27

Yogiyanto. (2007). Teori Portofolio dan Analisis Investasi. Yogyakarta: BPFE.

Zain, M. (2010). Manajemen Perpajakan (Pertama). Jakarta: Salemba Empat. 